\title{
Peertechz
}

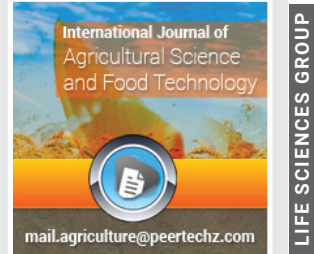

\section{Integrated management of} chocolate spot (Botrytis fabae Sard) through host resistance and fungicide application in the highlands of Bale, Southeastern Ethiopia

\author{
Ermias Teshome* and Dagne Kora
}

Sinana Agricultural Research Center, P.O.Box-208, Bale-Robe, Ethiopia
Received: 31 January, 2021

Accepted: 22 February, 2021

Published: 24 February, 2021

*Corresponding author: Ermias Teshome, Sinana Agricultural Research Center, P.O.Box-208, Bale-Robe, Ethiopia, E-mail: ermiastafa@gmail.com

Keywords: Chocolate spot; Integrated disease management; Fungicide; Host resistance

https://www.peertechzpublications.com

Check for updates

\section{Abstract}

Because of its nutritional value, Faba bean (Vicia faba L.) is one of the most important food legumes both as energy and protein source. It is among the most important pulse crops produced in Ethiopia in general and on the highlands of Bale in particular. Field experiment was conducted at Sinana Agricultural Research Center on-station using RCBD with three replications to study the integrated effect of fungicide (sprayed at various frequencies) and faba varieties to manage chocolate spot. The experiment consisted of five (5) fungicide application frequencies and two Faba bean varieties (Gebelcho and Mosisa). Logistic model, [In [(Y/1-Y)] was used to calculate the disease parameters such as disease progress rate ( $r$ ) and AUDPC. The partial budget analysis was carried out to asses financial profitability of fungicide application for the management of chocolate spot. ANOVA showed statistically significant difference $(P<0.05)$ among the treatments for the disease parameters. The lowest chocolate spot severity $(23.15 \%)$ and the best chocolate spot disease control was achieved from Gebelcho variety sprayed four times. Similarly, the lowest $r(-0.00453$ units/day) and AUDPC (823.1 \%-days) were recorded from Gebelcho variety sprayed four times. Regarding yield and yield components, ANOVA showed significant differences ( $<0.05)$ among the treatments. The highest number of pods per plant (15.28) was recorded from Gebelcho variety sprayed 2 times whereas, the highest TKW of $662.60 \mathrm{~g}$ was recorded from Gebelcho variety sprayed three times. In terms of grain yield, the maximum grain yield of $3515.44 \mathrm{~kg} / \mathrm{ha}$ was obtained from Mosisa variety sprayed four times and four times spray of Gebelcho variety gave the second highest grain yield of $3313.70 \mathrm{~kg} / \mathrm{ha}$. Partial budget analysis has shown the maximum marginal benefit of $41044.8 \mathrm{ETBha}^{-1}$ obtained from Mosisa variety sprayed four times at weekly interval while the second marginal benefit of $38624.4 \mathrm{ETBha}{ }^{-1}$ was obtained from Gebelcho variety sprayed four times at weekly interval. The maximum MRR of $1726.11 \%$ was obtained from Mosisa variety sprayed once and the second highest MRR (1592.84 $\%)$ was calculated from Gebelcho variety sprayed four times. Therefore, the recommendation is made depending on the results from the biological studies and partial budget analysis. For small scale farmers, it is recommended to produce Mosisa variety by spraying mancozeb $80 \%$ WP once to maximize the financial benefit from faba bean production. But, for small scale farmers who can afford, it is recommended to produce faba bean variety Mosisa sprayed three times by a fungicide mancozeb $80 \%$. However, for large scale farmers who are producing faba bean for export market are recommended to produce faba bean variety Gebelcho sprayed four times at 7-10 days interval.

\section{Introduction}

Faba bean (Vicia faba L.) is among the most important pulse crops produced in Ethiopia covering about 459, 183.51 ha of land with a total annual production of $697,798.39$ tyr $^{-1}$ [1]. The interest of farmers to produce faba bean in Ethiopia is growing because of the fact that its demand on the export market is increasing [2]. It is also one of the most important food legumes due to its high nutritive value both in terms of energy and protein contents (24-30\%) and also is an excellent nitrogen fixer. However, its average yield under smallholder farmers is very low, ranging from 1 to 1.2 tha $^{-1}$ [3]. Lack of or low adoption of high yielding cultivars, diseases, weeds and insect pests together with abiotic factors are the major constraints for Faba bean production [4]. Chocolate spot (Botrytis fabae Sard.) is one of economically important diseases that damages all 
parts of the crop and reduces faba bean production globally [5]. Similarly, it is one of the major faba bean yield limiting biotic factors for faba bean production in Ethiopia. Yield losses of up to $61 \%$ on a susceptible cultivar, and $34 \%$ on a tolerant cultivar were recorded in Ethiopia $[6,7]$. For its management, there are a number of possible options such as the use of moderately resistant/tolerant varieties, application of fungicides, biological control, induced resistance and cultural practices [3].

Host resistance is one of the most acceptable and economically profitable chocolate spot management options. However, host resistance alone is not a reliable management option of chocolate spot as faba bean varieties lack reliable resistance to the disease. Therefore, it is important to integrate faba bean varieties with fungicides and other cultural practices for the proper management of chocolate spot. The environmental conditions in the Faba bean growing areas of Bale highlands are conducive for chocolate spot development. A survey of chocolate spot disease in central Ethiopia showed $68 \%$ disease intensity [8]. As a result this disease need well developed management options. Sustainable management of chocolate spot needs epidemiological knowledge based management options based on fungicides, resistant cultivars and their integration with different cultural practices [9]. Indicated an option of early planting for the management of the disease. However, early planting may not be practical in regions where unreliable and erratic rainfall occurs frequently. Besides the importance of chocolate spot on Bale highlands, the effort towards the management of this disease is very minimal.

\section{Objective}

The study was conducted to study the integrated effect of fungicide (sprayed at various frequencies) and faba varieties to manage chocolate spot

\section{Materials and methods}

The field experiment was conducted during "bona" (main) cropping season at Sinana Agricultural Research Center (SARC) on-station and Agarfa sub-site field trials, for two consecutive years, 2017/18 and 2018/19. SARC is located at 463km away from the capital, Finfine to the south-east. Its geographic location is $07^{\circ} 07^{\prime} \mathrm{N}$ latitude and $40^{\circ} 10^{\prime} \mathrm{E}$ longitude with an elevation of 2400 masl. The area receives an annual rain fall of 750$1000 \mathrm{~mm}$ and has an annual temperature range of $9-21^{\circ} \mathrm{C}[10]$. The experiment was laid out in RCBD with 3 replications. Two faba bean varieties, Gebelcho (released from Holeta Agricultural Research Center in 2006 GC) moderately resistant to chocolate spot and Mosisa (released from Sinana Agricultural Research Center in 2013 GC) susceptible and tolerant to chocolate spot were used in this experiment. A fungicide Mancozeb $80 \%$ WP was sprayed in five (5) frequencies ( 0 times, 1 times, 2 times, 3 times and 4 times) at a rate of $2.5 \mathrm{~kg} / \mathrm{ha}$. The plot size was $2.4 \mathrm{~m} \times 3 \mathrm{~m}$ which contains 6 seeding rows. Between row, plot and replication spacing was $0.4 \mathrm{~m}, 2 \mathrm{~m}$ and $1.5 \mathrm{~m}$, respectively. The seed rates were 37 seeds for a $3 \mathrm{~m}$ long row (on the basis of $125 \mathrm{~kg} / \mathrm{ha}$ recommendation from SARC for small seeded varieties (Mosisa)) and 40 seeds for a $3 \mathrm{~m}$ long row (on the basis of $175-200 \mathrm{~kg} /$ ha recommendation from SARC for large seeded varieties (Gebelcho)). The fertilizer rate of $100 \mathrm{~kg}$ NPS/ ha was applied as non-experimental variable. The disease development was rated using 1-9 scoring scale, where, $1=$ No disease symptoms or very small specks; $3=$ few small discrete lesions; $5=$ some coalesced lesions with some defoliation; $7=$ large coalesced sporulating lesions, 50\% defoliation and some dead plant; and 9= Extensive lesions on leaves, stems and pods, severe defoliation, heavy sporulation, stem girdling, blackening and death of more than $80 \%$ of plants [11]. Disease scores were converted to Percent Severity Index (PSI) [12].

\section{Data collected}

The field data such as disease (severity and incidence) data, number of pods per plant, number seeds per pod, number of seeds per plant and data from laboratory which are TKW and grain yield were collected at an optimal time for collection. The disease severity data collected based on scoring scale was converted to percent severity index for analysis. All the collected data were fed to computer, cleaned and subjected to SAS statistical package for analysis.

\section{Data management and statistical analysis}

Logistic, $[\ln [(\mathrm{Y} / 1-\mathrm{Y})[5]$ and Gompertz, $-\ln [-\ln (\mathrm{Y})]$ [13], models were compared to estimate the disease parameters from each treatment. The logistic model was chosen based on the test of Goodness of the fit of the models using coefficient of determination $\left(\mathrm{R}^{2}\right)$. Therefore, variables for field experiment data under different treatments were analyzed using logistic model, $\ln [y /(1-y)]$ with the SAS Procedure [14]. Mean separation was made based on List Significance Difference (LSD) technique at 5\% probability level. AUDPC [15] and disease progress rate $(r)$ values were calculated for each plot using the formula indicated below. ANOVA was performed for disease severity index [12], AUDPC [15] and rate of disease progress ( $r$ ). The association of disease parameters with yield and yield related parameters was assessed using correlation and regression analysis.

$$
\begin{aligned}
& \text { PSI }=\frac{\text { Sum of Numerical Ratings X100 }}{\text { Number of Plants Scored X Maximum Score on Scale }} \\
& \text { AUDPC }=\sum_{i-1}^{n-1} 0.5\left(x_{i+1}+x_{i}\right)\left(t_{i+1}-t_{i}\right)
\end{aligned}
$$

Where, $\mathrm{X}_{\mathrm{i}}=$ the PSI of disease at the $\mathrm{i}^{\text {th }}$ assessment

$t_{i}=$ is the time of the $i^{\text {th }}$ assessment in days from the first assessment date

$\mathrm{n}=$ total number of disease assessments

\section{Cost-Benefit analysis}

The partial budget analysis was performed following the standard methodology, taking the variable costs in each treatment in to account (Table 1). The Marginal Rate of Return (MRR) was computed for each treatment (Table 2). The total income from each treatment was obtained as Sale Revenue (SR) 
Table 1: Variable costs associated with fungicide application for the management of Chocolate spot for Faba bean production.

\begin{tabular}{|c|c|c|c|c|c|c|c|c|c|c|}
\hline \multirow[b]{2}{*}{ No. } & \multirow[b]{2}{*}{ Treatment } & \multicolumn{2}{|c|}{ Fungicide } & \multicolumn{7}{|c|}{ List of items and activities as a source of costs (Ethiopian Birr) } \\
\hline & & $\begin{array}{c}\text { Rate } \\
\left(\text { kgha }^{-1}\right)\end{array}$ & Frequency & $\begin{array}{l}\text { Fungicide Cost } \\
\text { (ETH Birr/kg) }\end{array}$ & $\begin{array}{l}\text { Sprayer } \\
\text { rent }\end{array}$ & $\begin{array}{c}\text { Labor cost to } \\
\text { spray }\end{array}$ & $\begin{array}{l}\text { Labor cost for } \\
\text { water supply }\end{array}$ & $\begin{array}{l}\text { Cleaning } \\
\text { equipment }\end{array}$ & $\begin{array}{l}\text { Cost for } \\
\text { water }\end{array}$ & $\begin{array}{c}\text { Total variable } \\
\text { cost }\end{array}$ \\
\hline 1 & Mosisa No spray & 0 & 0 & 0 & 0 & 0 & 0 & 0 & 0 & 0 \\
\hline 2 & Gebelcho No spray & 0 & 0 & 0 & 0 & 0 & 0 & 0 & 0 & 0 \\
\hline 3 & Mosisa one time spray & 2.5 & 1 & 200 & 25 & 25 & 20 & 5 & 10 & 285 \\
\hline 4 & Gebelcho one time spray & 2.5 & 1 & 200 & 25 & 25 & 20 & 5 & 10 & 285 \\
\hline 5 & Mosisa two times spray & 2.5 & 2 & 400 & 50 & 50 & 40 & 10 & 20 & 570 \\
\hline 6 & Gebelcho two times spray & 2.5 & 2 & 400 & 50 & 50 & 40 & 10 & 20 & 570 \\
\hline 7 & Mosisa three times spray & 2.5 & 3 & 600 & 75 & 75 & 60 & 15 & 30 & 851 \\
\hline 8 & Gebelcho three times spray & 2.5 & 3 & 600 & 75 & 75 & 60 & 15 & 30 & 851 \\
\hline 9 & Mosisa four times spray & 2.5 & 4 & 800 & 100 & 100 & 80 & 20 & 40 & 1140 \\
\hline 10 & Gebelcho four times spray & 2.5 & 4 & 800 & 100 & 100 & 80 & 20 & 40 & 1140 \\
\hline
\end{tabular}

Table 2: Cost-benefit analysis of fungicide applications against Chocolate spot for Faba bean production.

\begin{tabular}{|c|c|c|c|c|c|c|c|}
\hline No. & Treatment & Fungicide $\left(\mathrm{kgha}^{-1}\right)$ & Yield $\left(\mathrm{kgha}^{-1}\right)$ & SR (ETB ha $\left.{ }^{-1}\right)$ & MC (ETB ha-1) & MB (ETB ha-1) & MRR (\%) \\
\hline 1 & Mosisa No spray & 0 & 2072.2 & 24866.4 & 0 & 24866.40 & 0.00 \\
\hline 2 & Gebelcho No spray & 2.5 & 1705.5 & 20466 & 0 & 20466.00 & 0.00 \\
\hline 3 & Mosisa one time spray & 2.5 & 2505.9 & 30070.8 & 285 & 29785.80 & 1726.11 \\
\hline 4 & Gebelcho one time spray & 2.5 & 1899 & 22788 & 285 & 22503.00 & 714.74 \\
\hline 5 & Mosisa two times spray & 2.5 & 2513.5 & 30162 & 570 & 29592.00 & 829.05 \\
\hline 6 & Gebelcho two times spray & 2.5 & 2090.7 & 25088.4 & 570 & 24518.40 & 710.95 \\
\hline 7 & Mosisa three times spray & 2.5 & 3160.7 & 37928.4 & 851 & 37077.40 & 1434.90 \\
\hline 8 & Gebelcho three times spray & 2.5 & 2433.1 & 29197.2 & 851 & 28346.20 & 686.63 \\
\hline 9 & Mosisa four times spray & 2.5 & 3515.4 & 42184.8 & 1140 & 41044.80 & 1419.16 \\
\hline 10 & Gebelcho four times spray & 2.5 & 3313.7 & 39764.4 & 1140 & 38624.40 & 1592.84 \\
\hline
\end{tabular}

SR: Sale Revenue; MC: Marginal Cost; MB: Marginal Benefit; MRR: Marginal Rate of Return

from the produced and sold faba bean in a rate of 12 ETB per kilogram of the product. The Marginal Cost (MC) is computed as a sum of all the variable costs incurred for the faba bean production and the Marginal Benefit (MB) is calculated as a difference of sale revenue and marginal cost (Tables 1,2).

The production cost and benefit from each treatment was analyzed using partial budget analysis. Similarly, the Marginal Rate of Return (MRR) was computed by considering the total variable costs incurred in each treatment. In this experiment the sum cost of fungicide, water, sprayer rental, labor for spraying, labor for water supply and labor for cleaning equipment were considered as variable costs. The MRR was used as major criteria which measures the effect of additional investment on net returns [16]. MRR provides the benefit value obtained as a function of the additional investment for the management of Chocolate spot in percentage.

$$
\operatorname{MRR}=\frac{\mathrm{DNI}}{\mathrm{DIC}} \times 100
$$

Where:- MRR: Marginal Rate of Return; DNI-Difference in Net Income compared with control, DIC; Difference in input cost compared with control.

\section{Results and discussion}

There was statistically significant difference $(P<0.05)$ among treatments for all the disease parameters, Chocolate spot
Disease Severity (\%), AUDPC (\%-days) and Disease Progress Rate (r) (units per day) (Table 3). On both varieties, there was not statistical difference between treatments for chocolate spot severity during the first two scoring periods. Similar the work of [17] and [18] justifies this result and they reported that there is not statistically justifiable difference between treatments regardless of the resistant level of faba bean varieties during the early stage of disease development. The maximum chocolate spot severity of $50 \%$ was recorded from unsprayed susceptible variety Mosisa. The second highest chocolate spot disease severity of $48.15 \%$ was recorded from Gebelcho variety with no fungicide spray whereas lower chocolate spot severity of $23.15 \%$ and $29.32 \%$ were recorded from Gebelcho variety sprayed four times and three times, respectively. Its agreed with similarly reported work that recorded the highest disease severity from unsprayed susceptible local variety while the lowest disease severity was recorded from moderately resistant Degaga variety sprayed at seven days interval [19]. Considering variety Mosisa, the lowest disease severity recorded was $29.63 \%$ after spraying the fungicide four times while the highest severity of $50 \%$ was recorded from unsprayed plot (Table 3 ). Again, this result is supported by [19] as they found that application of fungicide radically reduced disease severity and they observed high disease pressure on unsprayed plots. Chocolate spot severity showed an increasing trend with time as fungicide application frequency was decreasing (Figure 1). This trend was similarly reported by $[17,19]$ when they found the increasing trend of diseases severity and other disease parameters with 
the decreasing in fungicide application. Similarly [20] have also reported the reduction of disease severity as the fungicide application was reducing.

ANOVA for chocolate spot disease progress rate $(r)$ has shown statistically significant difference $(P<0.05)$ between treatments. Higher disease progress rates (r) of 0.23360 units/ day and 0.21370 units/day were recorded from unsprayed plots of Mosisa and Gebelcho varieties, respectively. On the other hand, lower disease progress rates of -0.00453 units/day and -0.00262 units/day were recorded from Gebelcho variety sprayed three times and four times, respectively. The same result was reported from the work of [21]. They reported the suppression of the apparent disease infection rate in sprayed plots by about six (6) times over unsprayed plots.

Table 3: Effect of Faba bean varieties and Fungicide application Frequencies on Chocolate spot Disease Severity (\%), AUDPC (\% days) and Disease Progress Rate ( $r$ ).

\begin{tabular}{|c|c|c|c|}
\hline Treatment & Chocolate spot PSI (\%) & $\mathbf{r}$ (units/day) & AUDPC (\%-days) \\
\hline Mosisa No spray & 50.00 & 0.23360 & 1730.6 \\
\hline Gebelcho No spray & 48.15 & 0.21370 & 1672.2 \\
\hline Mosisa one time spray & 42.59 & 0.04232 & 1477.8 \\
\hline Mosisa two times spray & 41.05 & 0.07252 & 1406.5 \\
\hline Gebelcho one time spray & 37.35 & 0.04293 & 1283.3 \\
\hline Gebelcho two times spray & 34.57 & 0.00667 & 1212.0 \\
\hline Mosisa three times spray & 34.26 & 0.00946 & 1199.1 \\
\hline Mosisa four times spray & 29.63 & 0.00093 & 1050.0 \\
\hline $\begin{array}{r}\text { Gebelcho three times } \\
\text { spray }\end{array}$ & 29.32 & -0.00262 & 1037.0 \\
\hline Gebelcho four times & 23.15 & -0.00453 & 823.1 \\
\hline spray & 7.88 & 0.10 & 273.44 \\
\hline LSD & 18.36 & 14.35 & 18.29 \\
\hline CV(\%) & &
\end{tabular}

Regarding AUDPC, statistically significant difference was observed between treatments $(P<0.05)$. The highest AUDP (1730.6\%-days) was recorded from unsprayed plot of Mosisa (susceptible) variety whereas the lowest AUDPC (823.1\%days) was recorded from Gebelcho (moderately resistant) variety sprayed four times (Table 4). Similarly [22] reported the highest AUDPC of $1817 \%$-days from susceptible faba bean variety which has not received any fungicide spray and the lowest AUDPC of 595\%-days from moderately resistant variety which has received fungicide spray at seven (7) days interval.

With regard to grain yield and yield components, ANOVA showed significant differences $(P<0.05)$ among the treatments for number of pods per plant (No. pod/plant), Thousand Kernel Weight (TKW) and grain yield (grain yield ( $\mathrm{kg} / \mathrm{ha})$ ). The highest number of pods per plant (15.28) and the lowest number of pods per plant (11.17) were recorded from Gebelcho variety sprayed two times and 1 time, respectively [23.24] reported that the highest number of pods per plant was recorded from moderately resistant variety sprayed with a fungicide. The highest and the lowest TKW of $662.60 \mathrm{~g}$ and $417.73 \mathrm{~g}$ were recorded from Gebelcho variety sprayed three times and Mosisa variety with no fungicide spray, respectively. Application of fungicide on moderately resistant faba bean variety increases thousand kernel weights of the faba bean grain [20,23]. Similarly [23,24], have also reported the reduction trend of faba bean TKW as the fungicide spray is decreasing.

Regarding grain yield, the highest grain yield of $3515.44 \mathrm{~kg} /$ ha was recorded from variety Mosisa sprayed four times whereas the lowest grain yield of $1705.5 \mathrm{~kg} / \mathrm{ha}$ was recorded from Gebelcho variety with no fungicide spray (Table 2). The fungicide application frequency influences faba bean yield as faba bean grain yield shows a decreasing trend with decreasing

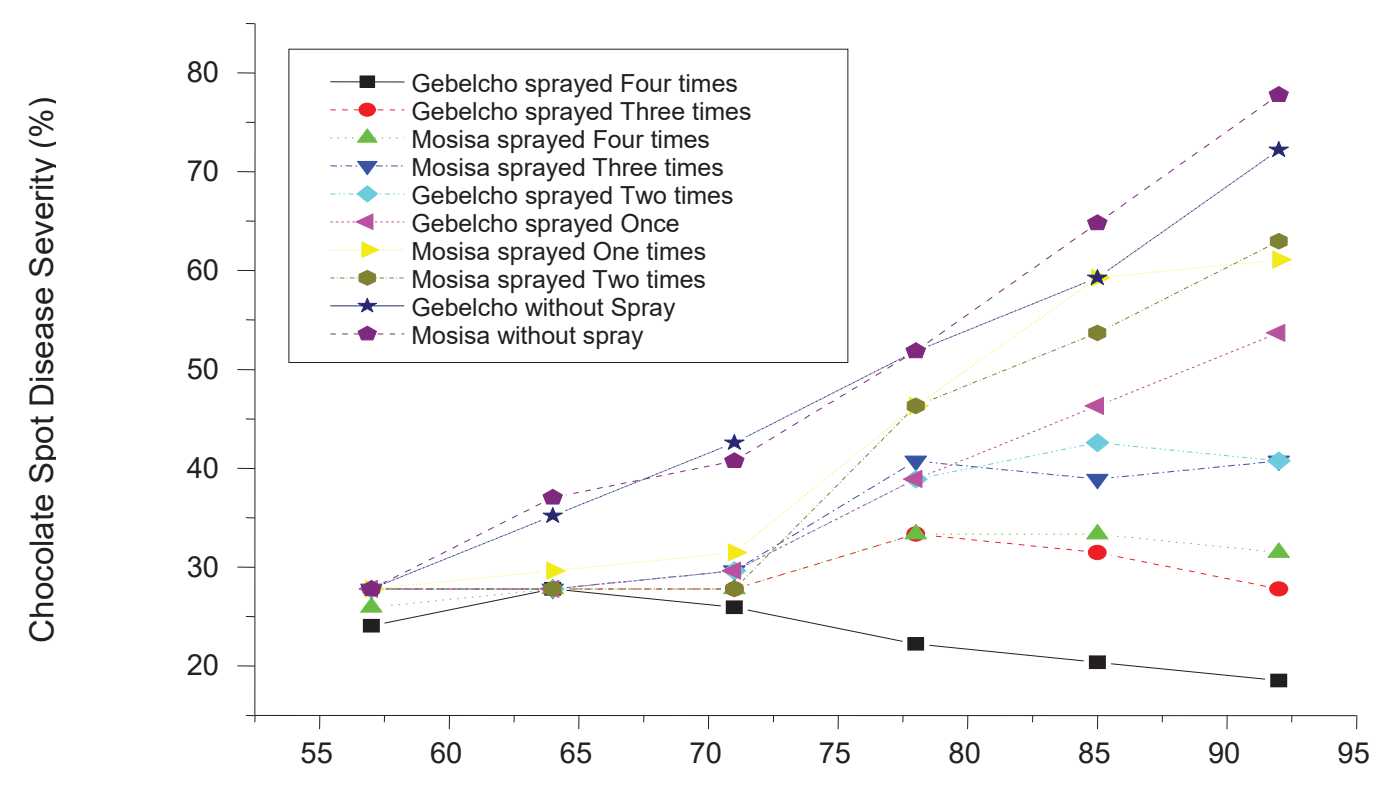

Days after planting (DAP)

Citation: Teshome E, Kora D (2021) Integrated management of chocolate spot (Botrytis fabae Sard) through host resistance and fungicide application in the highlands of Bale, Southeastern Ethiopia. J Agric Sc Food Technol 7(1): 086-091. DOl: https://dx.doi.org/10.17352/2455-815X.000093 
Table 4: The effect of varieties and fungicide application on disease severity, yield and yield components of faba bean

\begin{tabular}{|c|c|c|c|c|}
\hline Treatment & No. pod/plant & No. seed/plant & TKW & $\begin{array}{c}\text { Grain yield (kg/ } \\
\text { ha) }\end{array}$ \\
\hline Mosisa No spray & 13.78 & 14.06 & 417.73 & 2072.20 \\
\hline Gebelcho No spray & 13.61 & 15.06 & 564.43 & 1705.50 \\
\hline Mosisa one time spray & 12.50 & 16.11 & 435.17 & 2505.90 \\
\hline Gebelcho one time spray & 11.17 & 13.72 & 639.27 & 1899.00 \\
\hline Mosisa two times spray & 15.17 & 19.28 & 431.10 & 2513.5 \\
\hline $\begin{array}{l}\text { Gebelcho two times } \\
\text { spray }\end{array}$ & 15.28 & 18.06 & 660.87 & 2090.70 \\
\hline Mosisa three times spray & 12.83 & 15.22 & 442.43 & 3160.70 \\
\hline $\begin{array}{c}\text { Gebelcho three times } \\
\text { spray }\end{array}$ & 13.94 & 16.28 & 662.60 & 2433.10 \\
\hline Mosisa four times spray & 12.94 & 17.56 & 435.17 & 3515.40 \\
\hline $\begin{array}{l}\text { Gebelcho four times } \\
\text { spray }\end{array}$ & 13.33 & 13.33 & 646.80 & 3313.70 \\
\hline $\operatorname{LSD}_{(0.05)}$ & 3.63 & NS & 62.02 & 914.29 \\
\hline $\mathrm{CV}(\%)$ & 23.29 & 15.36 & 10.02 & 32.57 \\
\hline
\end{tabular}

fungicide application frequency [21]. Similarly [23,24] and [22] have found that faba bean grain yield has decreased when the fungicide application decreases and they found the highest grain yield from plots which have received the highest frequency fungicide application. Host plant resistance is also one of the varietal factor which influences fungicide application frequency and faba bean grain yield. This study has revealed the effect of host plant resistance on faba bean yield. Mosisa variety is found to be susceptible and tolerant to chocolate spot disease while Gebelcho variety is moderately resistant to chocolate spot. At all level of fungicide spray, the highest chocolate spot disease severity was recorded from Mosisa variety. But, regardless of the disease severity scores of Mosisa variety, the highest grain yield was recorded from Mosisa variety at all frequencies of fungicide spray. This is because of the tolerance of the Mosisa variety to chocolate spot.

\section{Partial budget analysis}

Partial budget analysis has depicted the highest marginal benefit of $41044.8 \mathrm{ETB}^{\mathrm{T}} \mathrm{ha}^{-1}$ from Mosisa variety sprayed with Mancozeb $80 \%$ WP four times at weekly interval and the second highest marginal benefit of $38624.4 \mathrm{ETB}^{-1}$ was recorded from Gebelcho variety sprayed four times. The lowest marginal benefit of 20466 $\mathrm{ETBha}^{-1}$ was obtained from unsprayed Gebelcho variety with no fungicide spray (Table 2). Similarly, the highest marginal rate of return (1726.11\%) was obtained from Mosisa variety sprayed once and the second highest marginal benefit of $1592.84 \%$ was recorded from Gebelcho variety sprayed four times using a fungicide mancozeb $80 \% \mathrm{WP}$. This indicates that for every 1.00 ETB invested to spray Mancozeb $80 \%$ WP to produce faba bean, it gives a return of 17.26ETB and 15.93ETB from Mosisa variety sprayed once and Gebelcho variety sprayed four times, respectively. Therefore, partial budget analysis has depicted that production of Faba bean variety Mosisa sprayed once with Mancozeb 80\% WP for the management of chocolate spot optimizes the profitability from faba bean production under small scale agriculture/small holder farmers' condition and production of faba bean variety Mosisa with four times application of fungicide also gives high marginal rate of return $(1419 \%)$ and the highest marginal benefit of $41044.8 \mathrm{ETB}^{\mathrm{T}} \mathrm{ha}^{-1}$ For those farmers who produces faba bean for export market, production of Gebelcho variety sprayed four times with a fungicide Mancozeb $80 \%$ WP maximizes the benefit from faba bean production.

\section{Discusion and conclusion}

Faba bean (Vicia faba L.) is one of the most important pulse crops produced in Bale highlands. It is also one of the most important food legumes due to its high nutritive value terms of protein contents $(24-30 \%)$ and also is an excellent nitrogen fixer. Regardless of the potential of the area to grow faba bean, there are numerous biotic and abiotic constraints limiting productivity of the crop. Chocolate spot disease is one of the major faba bean diseases limiting Faba bean productivity on the highlands of Bale. Chocolate spot epidemic occurs and causes significant yield losses in the highlands of Bale as most of the farmers are growing local cultivars.

The results from this experiment have shown that the application of fungicide, Mancozeb $80 \%$ WP has resulted in significant disease severity reduction and subsequent increment in yield. Hence, Fungicide is one of the key production packages of faba bean on the highlands of Bale and similar faba bean growing agro-ecologies. The highest grain yield of $3515.4 \mathrm{~kg} / \mathrm{ha}$ was recorded from Mosisa variety sprayed four times and the lowest grain yield of $1705.50 \mathrm{~kg} / \mathrm{ha}$ was obtained from Gebelcho variety with no spray. Partial budget analysis has depicted the highest Marginal Benefit (MB) of 41044.8ETBha ${ }^{-1}$ and the lowest $\mathrm{MB}$ of $20466 \mathrm{ETBha}^{-1}$ from Mosisa variety sprayed four times and Gebelcho variety with no fungicide sprays, respectively. The highest Marginal Rate Of Return (MRR) of $1726.11 \%$ and the lowest MRR of $686.63 \%$ were obtained from Mosisa variety sprayed once and Gebelcho variety sprayed three times, respectively. The plot with the highest marginal benefit (41044.8 $\left.\mathrm{ETBha}^{-1}\right)$ has found to have the third maximum MRR of $1419.16 \%$.

For small holder farmers Mosisa variety supported by three times of fungicide spray to maximize the marginal benefit to 41044.8 birr/ha for those who can afford to spray a fungicide three times. For large scale farmers who are producing the crop for export market, it is wise to recommend variety Gebelcho with four times application of a fungicide mancozeb $80 \% \mathrm{WP}$ for the management of chocolate spot which can give them a MRR of $1592.84 \%$ as this variety is a large seeded variety and has high demand on international market because of its seed size. The integrated system in general increased faba bean productivity and income benefit which can be recommended especially under subsistence farming system in Ethiopia.

\section{References}

1. CSA (Central Statistical Authority) (2011) Agricultural sample survey. Report on area and production of crops (private peasant holdings, meher season). Statistical Bulletin Vol. 1. Addis Ababa, Ethiopia

2. Sahile S, Fininsa C, Sakuja PK, Ahimed S (2008) Survey of chocolate spot (Botrytis fabae) disease of faba bean (vicia faba L.) and assessment of

Citation: Teshome E, Kora D (2021) Integrated management of chocolate spot (Botrytis fabae Sard) through host resistance and fungicide application in the highlands of Bale, Southeastern Ethiopia. J Agric Sc Food Technol 7(1): 086-091. DOI: https://dx.doi.org/10.17352/2455-815X.000093 
factors influencing disease epidemics in northern Ethiopia. Crop Protection 27: 1457-1463. Link: http://bit.ly/3bls3yL

3. Agegnehu G, Gizaw A, Sinebo W (2006) Yield performance and land-use efficiency of barley and faba bean mixed cropping in Ethiopian highlands. Eur J Agron 25: 202-207. Link: http://bit.ly/3aWCGPi

4. Degago $Y$ (2000) Faba Bean (Vicia faba) in Ethiopia. Institute of BiodiversityConservation and Research (IBCR). Addis Ababa, Ethiopia 43. Link: https://bit.ly/37QnAsK

5. Torres AM, Roman B, Avila CM, Satovic Z, Rubiales D, et al. (2004) Faba bean breeding for resistance against biotic stresses: towards application of marker technology. Euphytica 147: 67-80. Link: https://bit.ly/3aWw5nZ

6. Dereje G, Yaynu H (2001) Yield loss of crops due to plant diseases in Ethiopia Pest Manag J Ethiopia 5: 55-67. Link: http://bit.ly/3swvWO3

7. Sahile S, Abang MM, Fininsa C, Ahmed S, Sakhuja PK, et al. (2012) Pathogenic and genetic diversity of (Botrytis fabaeSand) isolates from faba bean fields in different agro-ecological zones of Northern Ethiopia. Archives of Phytopathology and Plant Protection 45: 1218-1236. Link: https://bit.ly/3d04W8M

8. Gorfu D, Beniwal SPS, Berhe A (1988) Screening faba bean lines for chocolate spot and rust resistance. IAR progress report on faba bean.Beniwal, S.P.S (Ed.). IAR, Addis Abeba, Ethiopia.

9. Gorfu D (1993) Studies on the epidemology of chocolate spot (Botrytis fabae Sard. ) of faba bean (Vicia faba L.). M.sc. Thesis, Alemaya University, Alamaya, Ethiopia 126

10. Kedir N, Tilahun G, Allo A (eds.) (2008) Fifteen years achievements: Oromia Agricultual Research Institute, Sinana Agricultural Research Center, BaleRobe, Southeast Ethiopia.

11. Bernier CC, Hanounik SB, Hussein MM, Mohamed HA (1993) Field manual of common faba bean diseases in the Nile Valley. International Center for Agricultural Research in the Dry Areas (ICARDA) Information Bulletin No. 3.

12. Wheeler JB (1969) An introduction to plant diseases. Wiley, london 347. Link: Link: http://bit.ly/3q03QJA

13. Berger RD (1981) Comparison of the Gompertz and Logistic equation to describe plant disease progress. Phytopathology 71: 716-719. Link: https://bit.ly/206RoKA
14. SAS Institute (1998) SAS/STAT guide for personal computers, version 6.12 edition. Cary, NC: SAS Institute.

15. Shaner G, Finney RE (1977) The effect of nitrogen fertilization in the expression of slow mildewing resistance in Knox wheat. Phytopathology 67: 1051-1056. Link: https://bit.ly/3dSsMjQ

16. CIMMYT (International Maize and Wheat Center) (1988) From Agronomic data to farmers' recommendations: An Economic training manual. Completely revised edition. CIMMYT, Mexico, D.F. Link: http://bit.ly/2ZUPzDj

17. Kora D, Hussein T, Ahmed S (2016) Epidemiology of chocolate spot (Botrytis fabae Sard.) on faba bean (Vicia faba L.) in the Highlands of Bale, Sinana district, Southeastern Ethiopia. Global Journal of Pests, Diseases and Crop Protection 4: 131-138. Link: https://bit.ly/3pSQr60

18. Bouhassan A, Sadiki M, Tivoli B (2004) Evaluation of a collection of faba bean (Vicia faba L.) genotypes originating from the Maghreb for resistance to chocolate spot (Botrytis fabae) by assessment in the field and laboratory. Euphytica 135: 55-62. Link: https://bit.ly/3bC2oaU

19. Bouhassan A, Sadiki M, Tivoli B (2004) Evaluation of a collection of faba bean (Vicia faba L.) genotypes originating from the Maghreb for resistance to chocolate spot (Botrytis fabae) by assessment in the field and laboratory. Euphytica 135: 55-62. Link: https://bit.ly/3bc2oaU

20. Teshome E, Tagegn A (2013) Integrated management of Chocolate spot (Botrytis fabae Sard.) of Faba bean (Vicia faba L.) at highlands of Bale south eastern Ethiopia. Research Journal of Agricultural and Environmental Management. 2: 011-014. Link: https://bit.ly/2ZXjomA

21. Bimrew Y, Shifa H (2018) Chemical Control of Faba Bean Chocolate Spot (Botrytis fabae) in Bale Highland, Ethiopia. Food Science and Quality Management 80: 45-53. Link: http://bit.ly/2037uFa

22. Kora D, Hussein T, Ahmed S (2017) Management of Chocolate Spot (Botrytis fabae L.) on Faba Bean in Bale Highland's, Ethiopia. Journal of Plant Sciences 5: 120-129. Link: http://bit.ly/3ku14el

23. El-Kholy RMA (2014) Chemical and Biological Control of Chocolate Spo Disease in Faba Bean under Field Conditions. Middle East Journal of Agriculture Research 3: 368-377. Link: http://bit.ly/3kxgb6L

24. Van der Plank JE (1963) Epidemiology of Plant Disease.New York and London Academic publishers 206.

\section{Discover a bigger Impact and Visibility of your article publication with}

\section{Peertechz Publications}

\section{Highlights}

* Signatory publisher of ORCID

* Signatory Publisher of DORA (San Francisco Declaration on Research Assessment)

* Articles archived in worlds' renowned service providers such as Portico, CNKI, AGRIS, TDNet, Base (Bielefeld University Library), CrossRef, Scilit, J-Gate etc.

* Journals indexed in ICMJE, SHERPA/ROMEO, Google Scholar etc.

* OAI-PMH (Open Archives Initiative Protocol for Metadata Harvesting)

* Dedicated Editorial Board for every journal

* Accurate and rapid peer-review process

* Increased citations of published articles through promotions

* Reduced timeline for article publication

Submit your articles and experience a new surge in publication services (https://www.peertechz.com/submission).

Peertechz journals wishes everlasting success in your every endeavours.

Copyright: @ 2021 Teshome E, et al. This is an open-access article distributed under the terms of the Creative Commons Attribution License, which permits unrestricted use, distribution, and reproduction in any medium, provided the original author and source are credited.

Citation: Teshome E, Kora D (2021) Integrated management of chocolate spot (Botrytis fabae Sard) through host resistance and fungicide application in the highlands of Bale, Southeastern Ethiopia. J Agric Sc Food Technol 7(1): 086-091. DOI: https://dx.doi.org/10.17352/2455-815X.000093 